\section{Crunch still ahead for archaeology congress}

THE planners of next vear's World Archaeological Congress at Southampton (England) have during the past week encountered mounting but conflicting pressures over the exclusion of South African scientists. The most ominous development is the decision of the International Union of Prehistoric and Protohistoric Sciences (IUPPS) to hold a special meeting of its executive committee (in Paris on 17 January 1986) to consider the matter. Meanwhile. the presidents of the Royal Society and the British Academy have spoken out against the exclusion, but the British committee organizing the congress has reaffirmed its earlier decision to ban South Africans.

The meeting of the executive committee of IUPPS (not to be confused with the British committee responsible for the congress) could affect what happens next year in Southampton. In principle the committee could decide to withdraw its imprimatur from the congress. In that case, according to Professor John Evans, the president of IUPPS who is also chairman of the British committee, it would be necessary to "consider again" the arrangements for next year"s congress.

The intervention of the presidents of the Royal Society and of the British Academy first took the form of a letter to The Times. On 17 November, Sir Andrew Huxley and Sir Randolph Quirk, speaking for their respective academies, referred to their "profound concern" at the decision to disinvite scientists from South Africa. They said that "it is an indispensable condition of holding an international conference that bona-fide scholars should be admitted irrespective of nationality, domicile or politics" and went on to describe the decision not to allow South Africans as "deplorable".

Huxley and Quirk went on to say that the decision could mean that Britain would cease to be regarded by bodies such as the International Council of Scientific Unions as "a fit place in which to hold an international scientific congress". Huxley expanded on this theme in his final anniversary address to the Royal Society last Saturday (30 November).

The meeting of the British National Committee on 20 November seems to have surprised those present by the weight of opinion in favour of continuing the ban. On one account, only one of a score of members spoke in favour of rescinding the ban. There are reports of overseas scientists having withdrawn from the congress, but the numbers are said to be "only about thirty". The possibility of moving the congress to another venue had been consi- dered. only to be discounted on the grounds of lack of time.

At Southampton, the organizers have a sense of having being misunderstood, even misrepresented. Professor Peter Ucko, the secretary of the organizing committee, says that nobody has appreciated the trouble that had been taken to ensure the attendance of genuine scientists from developing countries. In this respect, he says, there is every prospect that the congress will be a success. Moreover. it had been arranged that participants would attend as individuals, not as nominated delegates of national organizations.

But. Uckowent on to say, people do not appreciate that "you cannot now hold a conference and invite people from South Africa if you also hope that there will be people from up to thirty Third World countries". This is the reality. Ucko says that conference organizers cannot ignore.

The sequence of events leading to the ban on South Africans, beginning towards the end of the 1984-85 academic year, is not easily reconstructed. Ucko cannot at this stage recall whether the first representations came from the students at Southampton (whose union and, in particular, debating hall, is required for the congress) or from the local branch of the Association of University Teachers. The formal decision of the Southampton City Council to withdraw financial support came relatively late. he said. although there had been informal representations earlier in the summer.

Ucko, like many others involved in the conference organization. says that people have not paid enough attention to the moral indignation of those opposed to South African participation. The University of Southampton has not considered the trouble caused by its proposed hospitality for next year's conference, and may not do so. The vice-chancellor, $\mathrm{Mr}$ G.R. Higginson, said earlier this week that the university had no formal status in the congress except as the provider for accommodation during the university vacation. But Mr Higginson added that he had told the organizers during the summer that he saw no alternative to their decision to ban South Africans once the opposition to their presence had become apparent. $\square$

\title{
Keyworth resigns as US science adviser
}

Washington

DR George A. Keyworth III, President Reagan's science adviser since 1981, announced last week that he is to resign from the position before the end of the year. Keyworth is widely credited with having successfully defended basic science even while other budgets were being cut, but also earned some unpopularity for

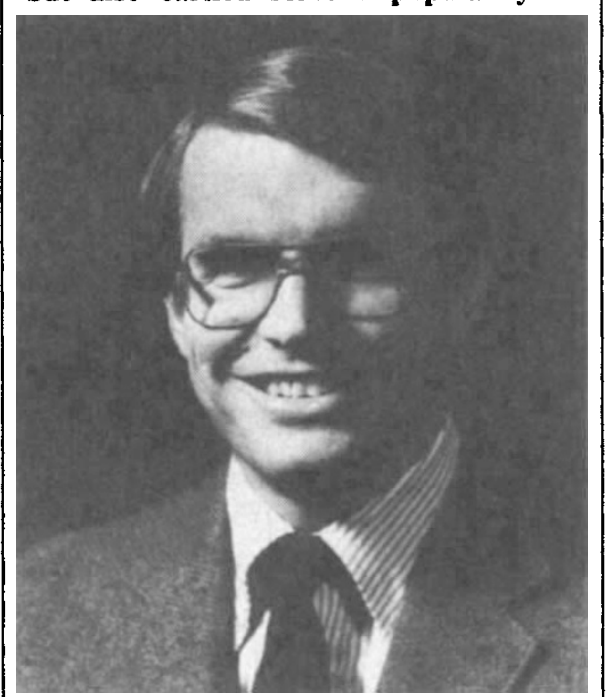

being identified very much as a member of Keagan's team rather than as an emissary of the scientific community.

Keyworth has been a staunch supporter of President Reagan's controversial Strategic Defense Initiative (SDI) programme of research into anti-ballistic mis- sile defences, which some fear could distort the pattern of financial support for basic research. But Keyworth said last week he was leaving at a time when everything was running smoothly: he was comfortable that SDI was on a firm footing and was encouraged by the general increased recognition of the importance of basic research, especially that conducted in universities.

William Carey, executive officer of the American Association for the Advancement of Science, said that Keyworth had earned a degree of access to the President that few other science advisers had achieved. He had also proven extremely effective in persuading the Office of Management and Budget to respect the importance of basic research, and had initiated important changes aimed at improving the efficiency of federal laboratories.

If Keyworth's term has been marked by generosity to basic science, his resignation comes at a time of widespread concern over the future level of support for science. Congress is considering legislation to reduce the federal budget deficit that would hit science hard, and many federal agencies have been told to expect budgets next year equal to or lower than this year's.

Keyworth is planning to establish a business with a former employee of the Central Intelligence Agency to advise companies on intelligence-gathering, where he is likely to command rather more than the $\$ 70,000$ salary he earned at the White House.

Tim Beardsley 